DOI: 10.4274/tpa.46.25

\title{
Ergenin müzik ile iletişimi
}

\section{Adolescent communication through music}

\author{
Cenk Erdem \\ Serbest Psikolog, İstanbul, Türkiye
}

\begin{abstract}
Özet
Ünlü Yunan Filozof Platon "Cumhuriyet" adlı ünlü eserinde genç insanların bedenleri için jimnastiğe ve ruhları için müziğe intiyaç duyduklarını söyler ve ergenlerin davranışlarını gözlemleyen herhangi bir yetişkin ergenlerin müzik ve sporla çok fazla vakit geçirdiklerini görebilir. Lull müziğin genç ergenler için özdeşleşme, bütünleşme ve kendini ifade etme şeklinde işlediğini ortaya koyar. Bu yüzden, ergenlerin müzik tercihleri iç dünyaları ve kişilik özellikleri hakkında bazı ipuçları verebilir; üstelik bu fenomen üzerindeki sosyal araştırmalar ergenlerin müzik tercihleri ve benlik kavramı arasında bağıntılar göstermektedir. Sonuç olarak ergenlerin müzik tercihlerini anlamaya çalışarak iletişim kurmak yetişkinlere yardımcı olabilir. (Türk Ped Arş 2011; 46 Özel Sayı: 19-21)
\end{abstract}

Anahtar sözcükler: Ergen, iletişim, müzik

\section{Summary}

Famous Greek Philosopher Plato states that young people need gymnastics for their bodies and music for their souls in his famous piece "The Republic" and any adult who observes the behaviours of adolescents can see that adolescents spend so much time with music and sports. Lull shows that music functions as identification, integration and expression for young adolescents. So, music preferences of adolescents may give some clues about their inner world and personality traits; further more social research on this phenomenon shows correlations between adolescents' music preferences and self-concept. As a result, it might be helpful for adults to communicate with adolescents through trying to understand their preferences for music. (Turk Arch Ped 2011; 46 Suppl: 19-21)

Key words: Adolescent, communication, music

\section{Giriş}

Ünlü Yunan filozof Platon, Cumhuriyet adlı eserinde (M.Ö. 4.yy 1968 çevirisi), gençlerin bedenleri için jimnastiğe ve ruhları için müziğe ihtiyaçları olduğu fikrini ileri sürer. Ergenin davranışlarını gözlemleyen herhangi bir yetişkin, ergenlik döneminde gençlerin spor ve müzik ile fazla zaman geçirdiklerine katılacaktır. Bu yüzden, günümüzde de Platon'un gözlemleri anlamlıdır (1).

Lull (2), genç insanların müziği her düzeyde otoriteye direnmek için, kişiliklerini ortaya koymak için, akran ilişkileri ve romantik gönül ilişkileri geliştirmek için ve ebeveynlerinin ve okullarının onlara anlatmadıkları ne varsa öğrenmek için kullandıklarını ortaya koymuştur.
Bu sebeple gençlerle sağlıklı bir iletișim kurarak onların gerçek dünyalarını anlayabilmek için müzik en önemli araçlardan biridir. Tercih ettikleri müzikler ergenler hakkında bize çok fazla ipucu verebilir.

Özellikle psikolojik sorunlar yaşayan ergenler ve genç yetişkinler üzerinde çalışmalar yapan araştırmacılar, psikolojik sorunlar yaşayan ergenlerin "heavy metal" ve "hard rock" gibi daha ağır müzik formlarını dinlemeyi tercih ettiklerini ortaya koymuştur (3-5).

Öte yandan ergenlerin müzik tercihlerinin benlik kavramı, bağımlılık-bağımsızlık meseleleri (6,7); değerler, inançlar, ve özdeşleşme kavramları ve benlik algısı ile ilişkili olduğu saptanmıştır (8-10). 
Müzik her yerde birden bulunan bir sosyal fenomendir. İnsanların müzik dinlemek için bir araya gelip sonra hakkında konuştukları konserler gibi, birçok sosyal etkinliğin merkezinde müzik vardır. İnsanların müzik tercihlerini etkileyen farklı sosyal ve psikoloji süreçler olsa da, temel kişilik özellikleri ve müzik tercihleri arasındaki bağı anlamak, kişiyi daha iyi anlamak için yardımcı olabilir.

Araştırmalar müziğin ergenler için önemli olduğunu, çünkü müzik sayesinde dış dünyaya bir kimlik tanımlayabildiklerini ve duygusal intiyaçlarını tatmin edebildiklerini göstermiştir (11).

\section{Ergen kimliği ve müzik}

Rentfrow ve Gosling 'in (12), müzik tercihleri ile kişilik özellikleri arasındaki bağıntıyı araştırdıkları çalışmalarında, sert ve isyankar müzikler (rock, alternatif, heavy metal v.b.) dinleyen bireylerin risk almaktan hoşlanan, fiziksel olarak etkin ve farklı şeylere meraklı kişiler oldukları; hareketli ya da geleneksel müzikler (film müzikleri, pop v.b.) dinleyen bireylerin neşeli, sosyal, güvenilir, başkalarına yardım etmekten hoşlanan ve kendilerini fiziksel olarak cazip bulan kişiler oldukları görülmüştür. Enerjik ve ritmik müzikler (rap/hip hop, dans/elektronik, soul/funk) dinleyenlerin konuşkan, enerjik, bağışlayıcı bireyler oldukları ve kendilerini çekici buldukları görülmüştür. Komplike ve yansıtıcı müzikler (blues, caz, klasik, folk) dinleyen bireylerin yeni deneyimlere açık, kendini zeki bulan, sözel becerileri kuvvetli ancak atletik becerilerle negatif ilintili bireyler oldukları saptanmıştır.

North ve Hargreaves (11) yaptıkları araştırmada, müzik tercihlerinin farklı şekillerde işlediğini, hem kişinin kendisini nasıl gördüğünü, hem de başkalarına nasıl göstermek istediğini belirleyen bir iletişim yolu olduğunu saptamışlardır.

Ergenler müziği bir mesaj vermek için, kim olduklarını göstermek için ya da nasıl bilinmek istediklerinin mesajını vermek için kullanabilirler. Bu anlamda müzik ergen için en güçlü iletişim araçlarından biridir.

Schwartz ve Fouts (13) araştırmalarında müzik dinleme davranışının sıklıkla gelişimsel süreçle ilgili olduğunu ortaya koymuşlardır.

Yine Schwartz ve Foutz (13) farklı müzik tercihleri ve farklı ergen kişilikleri üzerine yaptıkları çalışmada hard rock, klasik rock, heavy metal ve rap gibi sert tarz müziklerin, hiperseksüellik, kadınlara daha az saygı gösterme, daha çok suç davranışı sergileme ve antisosyal davranışlar gibi davranış şekilleriyle ilintili olduğunu göstermişlerdir. Pop ve dans gibi hafif müzik türlerini tercih eden ergenlerin doğru ve uygun olanı yapmakla daha çok ilgilendikleri ortaya çıkmıştır. Ayrıca hafif müzikler dinleyenlerin iki gelişimsel mesele olarak özellikle cinsellikleri ve akranlarıyla ilişkileri üzerinde durduklarını saptamışlardır. Hafif müzikler dinleyen gençler çocukluk dönemi inançları ile yeni cinsel dürtüleri arasında bir uzlaşmaya varmak konusunda daha çok zorlanan gençler olarak görülmüşlerdir. Akranlar tarafından kabul görmek ergen için önemli bir mesele olduğundan, pop müzik dinlemek diğer dinleyenlerle daha çok paylaşabilmenin bir yolu olabilir. Öte yandan aynı araştırmada eklektik bir müzik dinleme davranışı gösteren, her tarz müzik dinleyen gençlerin ergenlik dönemi ile baş etmek konusunda daha az zorlandıkları tespit edilmiştir. Sadece hafif müzikler dinleyen ya da sadece sert müzikler dinleyen gençlere göre, her tarz müzik dinleyen gençlerin, benlik kavramı, otorite, cinsel kaygılar ve akran ilişkileri konularında ya da akademik konularda ve aile ilişkilerinde anlamlı sorunlar yaşamadıkları görülmüştür. Bu gençlerin müziği ruh hallerine göre (duygularını yansıtmak ve duygularının altını çizmek için, ruh halini değiştirmek için vb), ortama göre (yalnız başına, arkadaşlarıyla vb), ve o anki intiyaçları doğrultusunda daha esnek şekilde kullandıkları saptanmıştır.

Ergenin tercih ettiği müziklerin kimliği hakkında verdiği ipuçlarını ortaya koyan çalışmalarda, özellikle "heavy metal" gibi sert müzikleri dinleyen gençlerin iç dünyaları ile ilgili bulgular dikkat çekicidir.

Arnett (14) ergenlerin yabancılaşması kuramını "heavy metal" alt kültürünü açıklamak için kullanır. Bu çerçevede toplumdaki bireysellik ve önemli sosyal kurumlardaki (aile, okul, din, v.b.) erozyon ergenlerde yabancılaşma duyguları yaratabilir ve bu gençleri belirli müzik tercihlerine dayanan alt kültürler yaratmaya ya da bu alt kültürlere katılmaya yöneltebilir. Bu alt kültürler bilinç düzeyinde ya da bilinç altında kendilerine ait bireysel değerleri, tutumları, ve psikolojik ruh hallerini yansıtmakta ve onaylamakta işe yarayabilir. Birçok çalışmada "heavy metal" alt kültürüne dahil olan gençlerin bazı özelliklerinin, intihar eğilimli gençlerin özelliklerine benzediği saptanmıştır (15-17). Burada "heavy metal" dinlemek ile intihar eğilimi arasında neden sonuç ilişkisi çıkarmak ne kadar yanlış ise, bu alt kültürün intihar için belirli risklerin ipucunu verdiği gerçeğini gözden kaçırmakta, o kadar yanlış olur. Bu nedenle gençlerin dinledikleri müzikleri tanımak, gençleri dinledikleri müziklerle anlamaya çalışmak, ergen ile iletişimde çok önemlidir.

Dünyada bugüne kadar intihar kurbanı gençlerin aileleri arasında, bazı "heavy metal" gruplarına dava açanlar olmuştur. 1999 yılının Nisan ayında gerçekleşen cinayet-intihar vakasının ardından medya ünlü sanatçı Marilyn Manson'ın müziklerinin olası etkileri üzerinde durmuştur. Rock müziğinin ortaya çıktığı ilk günlerden beri, ergenlerin müzik tercihleri, özellikle bu türün şarkı sözlerindeki cinsellik, uyuşturucu ve intihar konularından dolayı ailelerin ve sağlık alanındaki profesyonellerin tartıştığı konulardan biri haline gelmiştir.

Lacourse ve ark. (18) "heavy metal" müziği ve ergenin intihar riski üzerine yaptıkları araştırmada, "heavy metal" müzik tercihinin sadece intihar riski ile bağıntılı olmadığını, ayrıca kızlarda yabancılaşma, erkeklerde ise madde kullanımı ile bağıntılı olduğunu saptamışlardır. Araştırmada "heavy metal" dinleyen ergenler daha çok alkol tüketmeye ve madde kullanmaya eğilimlidir sonucuna varılırken, bu müziği saldırgan duygularla başa çıkmak için kullandıkları saptanmıştır. 
Bu tür müziği olumsuz duygulardan kurtulmak ve rahatlamak için kullanmak açısından sadece kızların yararlandığı anlaşıımışıı. Öte yandan bu tür müziği rahatlamak için kullanan kızların daha çok psikolojik sorunlar yaşadığı saptanmıştır.

Aynı araştırma ergenin davranış özelliklerinin oluşturduğu intihar riskinin, müzik tercihinden daha önemli bir rol oynadığını saptasa da, ebeveynler için gencin dünyasına girmek açısından, dinlediği müzik türünü ve alt kültürlerini tanımak çok önemlidir. Sert müzikler dinleyen gençlerin kimlik oluşumu ile ilgili bir sorun olabilir ve/ veya gelişimsel olarak takıldıkları alanların sinyalleri alınıyor olabilir ve hatta ergen, Erikson'un (19) negatif benlik olgusunu sergiliyor olabilir.

\section{Ergen cinselliği ve müzik}

Müzik gençlerin yaşantısından ayrıştırlamaz bir iletişim yoludur ve popüler müzik erken yaşta etkin bir cinselliği tetikleyebilir. Bir ergen günde 1,5-2 saat müzik dinler ve cinsel temalar dinledikleri müzikler içinde sıklıkla kullanılır. Ancak, bu temalar romantik ve flörtöz olabildiği gibi cinselliği aşağılayan temalar da olabilir. Müzik ergenin cinsel davranışları üzerinde de önemli bir rol oynayabilir. Popüler müzik gencin hayatında önemli bir yer kapladığından, gencin davranışlarını dinledikleri müzikleri dikkate almadan anlamak mümkün değildir. Genç müzik yoluyla toplum hakkında ve sosyal konularda olduğu gibi, cinsiyet rolleri ve kendisinden beklenen davranışlar konusunda da bilgi edinir. Tüm bunlar kendi kimliğinin oluşmasında etkilidir.

Ergenlerin cinsel davranışları ve müzikteki cinsel içerik konusunda yapılan tek araştırmada Pardun ve ark. (20) popüler müziklerdeki sözleri incelemiş ve cinsel gelişme, romantik ilişkiler ve cinsel davranışlar üzerindeki etkisini araştırmıştır. Araştırmada gençlerin ne kadar çok cinsel içerikli şarkı dinlediğine bağlı olarak, o kadar çok cinsel açıdan etkin olmaya eğilimli olduklarını saptamıştır. Yüksek düzeyde cinsel içerikli şarkılar dinleyen gençlerin, cinsel açıdan etkin davranışları artabilir ya da daha ileride daha etkin olma arzusu ortaya çıkarabilir yorumlarını yapmıştır.

Aşıı pop müzik dinlemenin içeriğinden bağımsız olarak gençleri daha çok uyardığı ortaya konulmuştur. Bu belki de pop yıldızlarının sözlerden daha etkin olarak cinsel davranışları etkilediği bağıntısını da ortaya koyabilir.

Ailelerin tüm bu bilgiler ışığında çocuklarının neler dinlediğini, ne tür sanatçllardan ve ne tür müziklerden hoşlandığını bilmesi, ergenleri anlamak açısından en güzel yollardan biri olabilir. Ergenler müzik tercihlerini belirleyen birçok etken ile birlikte öncelikle nasıl bir çevrede oldukları ile ilgi olarak da tercihlerde bulunurlar. Bu yüzden anne ve babanın dinlediği müzikler de çocuğun tercihleri için önemlidir. Özellikle cinsellik açısından kadını bir cinsel nesne gibi gösteren ya da erkeği doyumsuz bir avcı gibi öven imajların yüklendiği video klipleri tartışmak, izah etmek, her konuyu olduğu gibi müziği de konuşmak iletişime çok yardımcı olabilir. Araştırmalar farklı tür müziklerle, antisosyal davranışlar, madde kullanımı ve intihara yatkınlık arasında bağıntılar ortaya koymuştur. Kimi genç nasıl olmak istediğini göstermek ya da vermek istediği mesajı iletmek için müziği seçiyor olabilir. Genci anlayabilmek için, onun dünyasına girerek içinde olup bitenleri görebilmek için ergenle iletişimde müzik hem çok hızlı hem de kolay bir yoldur.

\section{Kaynaklar}

1. Holmes GR. Helping Teenagers into Adulthood. A guide for the next generation, Wesport CT, 2. 1995; 2: 17.

2. Lull J. Popular music and communication. Boston: Sage publications inc 1987: 152.

3. Hansen $\mathrm{CH}$, Hansen RD. Cultivation of Personality and Social Reality Through Music: Individual Differences Among Fans of Punk and Heavy Metal Music. Unpublished manuscript: Oakland University, 1990.

4. Took KJ, Weiss DS. The relationship between heavy metal and rap music and adolescent turmoil: Real or artifact? Adolescence 1994; 29: 613-21. (Abstract)

5. Wass H, Raup JL, Cerullo K, Martel LG, Mingione LA, Sperring AM. Adolescents' interest in and views of destructive themes in rock music. Omega 1989; 19: 177-86. (Abstract)

6. Avery R. Adolescents' use of the mass media. Am Behav Sci 1979; 23: 53-70.

7. Mainprize S. Interpreting adolescents' music. J Child Care 1985; 2: 55-62.

8. Arnett JJ. Adolescents' uses of media for self-socialization. $J$ Youth Adolesc 1995; 24: 519-33. (Abstract) I (PDF)

9. Larson R. Secrets in the bedroom: Adolescents' private use of media. J Youth Adolesc 1995; 24: 535-50. (Abstract) / (PDF)

10. White A. Meaning and effects of listening to popular music. $J$ Counse Dev 1985; 64: 65-9.

11. North AC. Hargreaves DJ. Music and adolescent identity. Music Educ Res 1999; 1: 75-92. (Abstract)

12. Rentrow PJ, Gosling SD. The structure and personality correlates of music preferences. J Pers Soc Psychol 2003; 84: 1236-56. (PDF)

13. Schwartz K, Fouts G. Personality of adolescents and amount of time listening to music. Paper presented to the Western Psychological Association, Albuquerque, NM, April 1998.

14. Arnett JJ. Metal Heads: Heavy Metal Music and Adolescent Alienation. Colorado: Westview Press Boulder CO, 1996.

15. Arnet JJ. Heavy metal music and reckless behavior among adolescents. J Youth Adolesc 1991; 20: 573-92. (Abstract) / (PDF)

16. Stack S. Heavy metal, religiosity, and suicidal acceptability. Suicide Life Threat Behav 1998; 28: 388-94. (Abstract)

17. Weinstein D. Heavy Metal: A Cultural Sociology. New York: Macmillan, 1991.

18. Lacourse E, Claes M, Villeneuve M. Heavy Metal Music and Adolescent Suicidal Risk. J Youth Adolesc 2001; 30: 321-32. (Abstract) / (PDF)

19. Erikson E. Identity: Youth and Crisis. New York: WW Norton, 1968.

20. Pardun CJ, L'engle KL, Brown JD. Linking exposure to outcomes: Early adolescencents' consumption of sexual content in six media. Mass Comm Society 2005; 8: 75-91. (Abstract) 